\title{
Buried ice in Kennar Valley: a late Pleistocene remnant of Taylor Glacier
}

\author{
KATE M. SWANGER \\ Department of Environmental, Earth and Atmospheric Sciences, University of Massachusetts, 1 University Avenue, \\ Lowell, MA01854, USA \\ Kate_Swanger@uml.edu
}

\begin{abstract}
Buried glacier ice is common in the McMurdo Dry Valleys and under ideal climatic and geomorphological conditions may be preserved for multimillion-year timescales. This study focuses on the analysis of $\sim 300 \mathrm{~m}^{2}$ of buried glacier ice in lower Kennar Valley, Quartermain Range. The mapped ice is clean, $<10 \mathrm{~m}$ thick and covered by a $\sim 25 \mathrm{~cm}$ sandy drift. The mouth of Kennar Valley is occupied by a lobe of Taylor Glacier, an outlet glacier from Taylor Dome. Based on ice-sediment characteristics, air bubble concentrations and stable isotopic analyses from three ice cores, the lower Kennar Valley ice is glacial in origin. These data coupled with a previously reported exposure age chronology indicate that the buried ice was deposited by a late Pleistocene advance of Taylor Glacier, probably during an interglacial interval. The surface of the buried glacier ice exhibits a patterned ground morphology characterized by small, dome-shaped polygons with deep troughs. This shape possibly reflects the final stages of ice loss, as stagnant, isolated ice pinnacles sublimate in place. This study highlights how polygon morphology can be used to infer the thickness of clean buried ice and its geomorphological stability throughout Antarctica, as well as other in cold, arid landscapes.
\end{abstract}

Received 14 March 2016, accepted 31 October 2016, first published online 31 January 2017

Key words: Antarctica, cold-based glacier, geomorphology, polygons, stable isotopes, sublimation

\section{Introduction}

Buried ice is common in the McMurdo Dry Valleys (MDV) of Antarctica. However, the age, origin and stability of this ice is variable, from the rapidly melting Last Glacial Maximum (LGM) ice in Garwood Valley (Levy et al. 2013) to the multimillion-year-old ice reported for Beacon Valley (Sugden et al. 1995, Marchant et al. 2002) (Fig. 1). In addition to buried glacier ice, much of the MDV soils contain shallow ice cement (pore ice), even the hyper-arid upland regions (Marchant \& Head 2007, Marinova et al. 2013). Due to the heterogeneity in the origin of buried ice, these deposits are potential indicators of past glacial, hydrologic and climatic conditions throughout the MDV. As such, they are important features that need to be better mapped and characterized throughout much of the region.

In the high elevation Quartermain Range (Fig. 1), buried glacier ice is especially extensive in Beacon and Mullins valleys, where reported ice ages range from Pleistocene to mid-Miocene (Sugden et al. 1995, Marchant et al. 2002). Due to its potential antiquity, the buried ice in Beacon Valley has been studied extensively and therefore its characteristics, such as thickness, geochemistry and stratigraphy, are well documented (Marchant et al. 2002, Kowalewski et al. 2011, Mackay et al. 2014, Yau et al. 2015). Although Beacon Valley exhibits the most extensive buried ice deposits in the Quartermain Range, similar deposits occur nearby, most notably in Kennar Valley (Fig. 1). The buried ice in Kennar Valley is relatively unstudied and could provide complementary data on past fluctuations of outlet glaciers (Swanger et al. 2011), the processes that govern sublimation till development (Kowalewski et al. 2011), and the variable age and degradation of buried ice in this sector of Antarctica.

\section{Background and setting}

The McMurdo Dry Valleys and Taylor Glacier

Located in the central Transantarctic Mountains, the MDV lie at $77^{\circ} \mathrm{S}$ and $160^{\circ} \mathrm{E}$, between the East Antarctic Ice Sheet (EAIS) and the Ross Sea (Fig. 1). The MDV cover an area of $\sim 4500 \mathrm{~m}^{2}$ and have a total relief of $\sim 2800 \mathrm{~m}$ (Levy 2013). Major east-west trending valleys, each $\sim 80 \mathrm{~km}$ long and up to $15 \mathrm{~km}$ wide, extend across the region (Fig. 1).

Outlet glaciers from the EAIS flow through the major valleys and alpine glaciers flow from the mountain ranges. One such outlet glacier is the $75 \mathrm{~km}$ long Taylor Glacier, which flows eastward from Taylor Dome and terminates in central Taylor Valley $\sim 40 \mathrm{~km}$ from the Ross Sea coast (Fig. 1). In its upper reaches, where it 


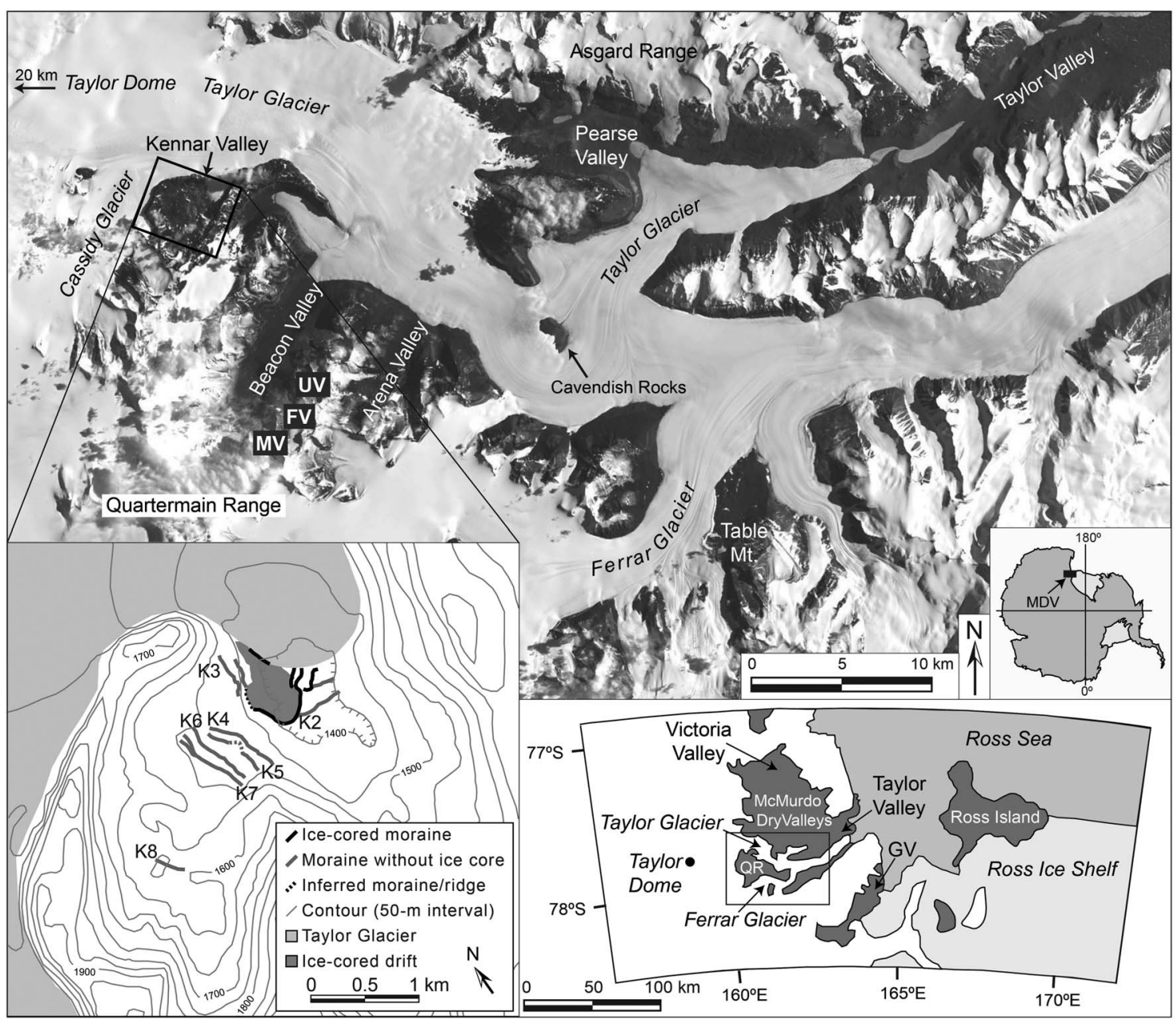

Fig. 1. Map of Kennar Valley in the Transantarctic Mountains (Landsat7 image courtesy of NASA Goddard Space Flight Center and US Geological Survey). Left lower inset: Topographical map of Kennar Valley showing location of ice-cored drift as well as its relationship to modern Taylor Glacier and a suite of ice-cored moraines and drop moraines, named K2-K8 (after Swanger et al. 2011). Right lower inset: Regional setting for the McMurdo Dry Valleys (MDV), Taylor Glacier and Taylor Dome. $\mathrm{FV}=$ Farnell Valley, MV = Mullins Valley, QR = Quartermain Range, UV = University Valley.

flows past the Quartermain Range, Taylor Glacier is $\sim 1000 \mathrm{~m}$ thick, cold-based and largely non-erosive (Kavanaugh et al. 2009b). On the basis of repeat GPS surveys and synthetic aperture radar interferometry (InSAR), ice surface velocities for upper Taylor Glacier are $\sim 5-10 \mathrm{~m} \mathrm{yr}^{-1}$ (Kavanaugh et al. 2009b).

Evidence for past changes in the elevation and areal extent of Taylor Glacier comes from mapped moraines and drift sheets within the Quartermain Range (Brook et al. 1993, Marchant et al. 1994, Swanger et al. 2011) and in Taylor Valley (Higgins et al. 2000, Swanger et al. 2010) (Figs $1 \& 2$ ). These dated glacial chronologies indicate relatively minor advances of Taylor Glacier during the late Pliocene to present. Evidence from central Taylor Valley indicates that from 130000 to 70000 years ago, Taylor Glacier thickened in this region by $\sim 200 \mathrm{~m}$ (Higgins et al. 2000).

\section{Quartermain Range climate and geomorphology}

The Quartermain Range, situated in the south-western MDV, comprises $\sim 500 \mathrm{~km}^{2}$ of high elevation mountains dissected by four north-east trending valleys (Fig. 1). Environmental conditions in the Quartermain Range are among the coldest and driest in the MDV. Mean annual atmospheric temperatures are $<-20^{\circ} \mathrm{C}$ and temperatures during the summer rarely exceed $0^{\circ} \mathrm{C}$ (Doran et al. 2002, Marchant \& Head 2007). Precipitation is $<30 \mathrm{~cm}$ of water equivalent per year (Fountain et al. 2009).

Buried ice is common throughout the Quartermain Range, and includes interstitial pore ice and clean massive ice. The former is probably recharged via occasional, isolated meltwater infiltration near snowbanks and/or vapour condensation (McKay 2009, Lacelle et al. 2013). Whereas, the latter probably reflects past advances of 

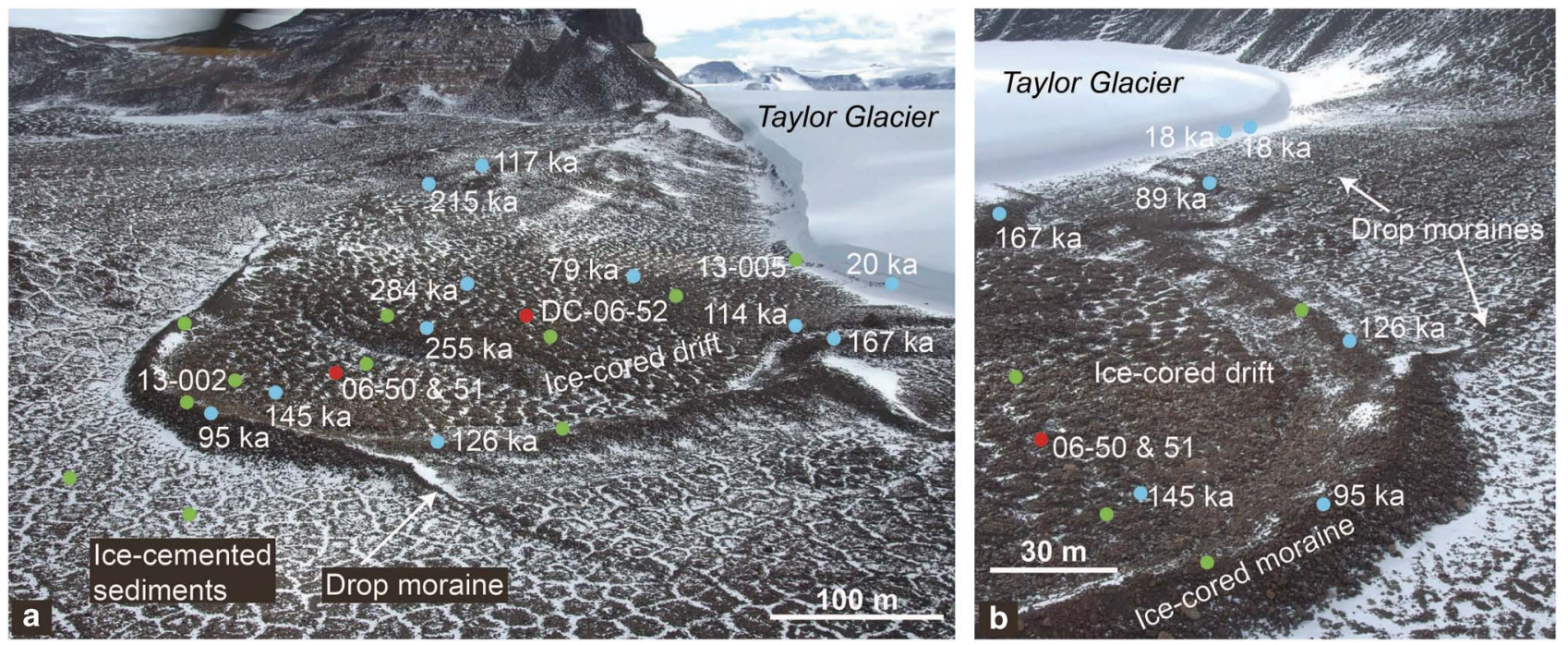

Fig. 2. Oblique aerial photographs of the ice-cored drift, ice-cored moraines and drop moraines in lower Kennar Valley, adjacent to the modern lobe of Taylor Glacier. Blue circles $=$ uncorrected ${ }^{3} \mathrm{He}$ exposure ages of surface clasts (Swanger et al. 2011). The three youngest dates $(18-20 \mathrm{ka})$ are from clasts imbedded in Taylor Glacier terminus. Red circles $=$ ice cores. Green circles $=$ sediment excavations. Labels refer to excavations specifically referenced in text, with additional (unlabelled) excavations that were used in analyses. Note complex moraine-drift relationships, indicating multiple advances and retreats of Taylor Glacier. a. Image is looking north and b. image is looking east.

outlet (Marchant et al. 2002) and alpine glaciers (Pollard et al. 2012, Mackay et al. 2014). Some of the buried glacier ice in central Beacon Valley (Sugden et al. 1995) has received considerable attention because of its reported age in excess of $8.1 \mathrm{Ma}$ (Sugden et al. 1995) and its complex history related to major expansion(s) of Taylor Glacier (Marchant et al. 2002). Apart from the extensive buried ice in Beacon Valley and its tributary cirques, the only other mapped (major) clean ice body in the Quartermain Range is found in Kennar Valley, at the valley mouth (Swanger et al. 2011) (Fig. 1).

Where ice cement and massive ice lie $<100 \mathrm{~cm}$ below the ground surface in the Quartermain Range, contraction-crack polygons tend to form (Mellon et al. 2014). During winter months, this subsurface ice contracts under temperature-driven tensile stresses, forming long, thin vertical cracks. The cracks may infill with loose sands, preventing closure during the summer months (Marchant et al. 2002). Based on the nature of the subsurface ice and the environmental conditions, two main types of polygons may form: i) low-relief, sandwedge polygons typical in ice-cemented soils and ii) highrelief, sublimation-type polygons in massive buried ice deposits (Marchant \& Head 2007).

The main morphologic difference between sand-wedge polygons and sublimation-type polygons is the relief between polygon troughs (the contraction crack) and polygon centres. For sand-wedge polygons, troughs are typically $<30 \mathrm{~cm}$ deep, whereas in sublimation-type polygons troughs may reach depths of $3 \mathrm{~m}$. In the latter, deep troughs form as sublimation of buried ice preferentially occurs at these sites, resulting in localized rates of mass loss that are greater in polygon troughs than in polygon centres (Marchant \& Head 2007). Eventually, a new network of contraction cracks may emerge as a result of changing thermal stresses, resulting in multiple polygon generations over time (Kowalewski et al. 2011). Large troughs tend to accumulate thick packages of sands, cobbles and boulders, as well as snowbanks, which together protect the underlying ice from seasonal thermal fluctuations, further diminishing tensile stress in troughs as they deepen (Marchant et al. 2002).

\section{Kennar Valley geomorphology}

Kennar Valley is located where Taylor Glacier first bends eastward toward the coast $\left(\sim 77^{\circ} 45^{\prime} \mathrm{S}, 161^{\circ} 24^{\prime} \mathrm{E}\right)$. The lobe of Taylor Glacier that occupies the mouth of Kennar Valley displays a clean ice ramp, terminating at $\sim 1400 \mathrm{~m}$ elevation (Fig. 1). Elsewhere the valley is predominantly free of exposed glacier ice (Figs $1 \& 2$ ). Sources for debris entrainment within the cold-based Taylor Glacier include ice-marginal bedrock cliffs of Ferrar Dolerite and Beacon Supergroup conglomerates, sandstones and shales (McElroy \& Rose 1987, Elliot \& Fleming 2004). Clasts are then transported as englacial and supraglacial debris before being deposited in Kennar Valley. All such lithologies are present within the drifts in lower Kennar Valley (Swanger et al. 2011). 

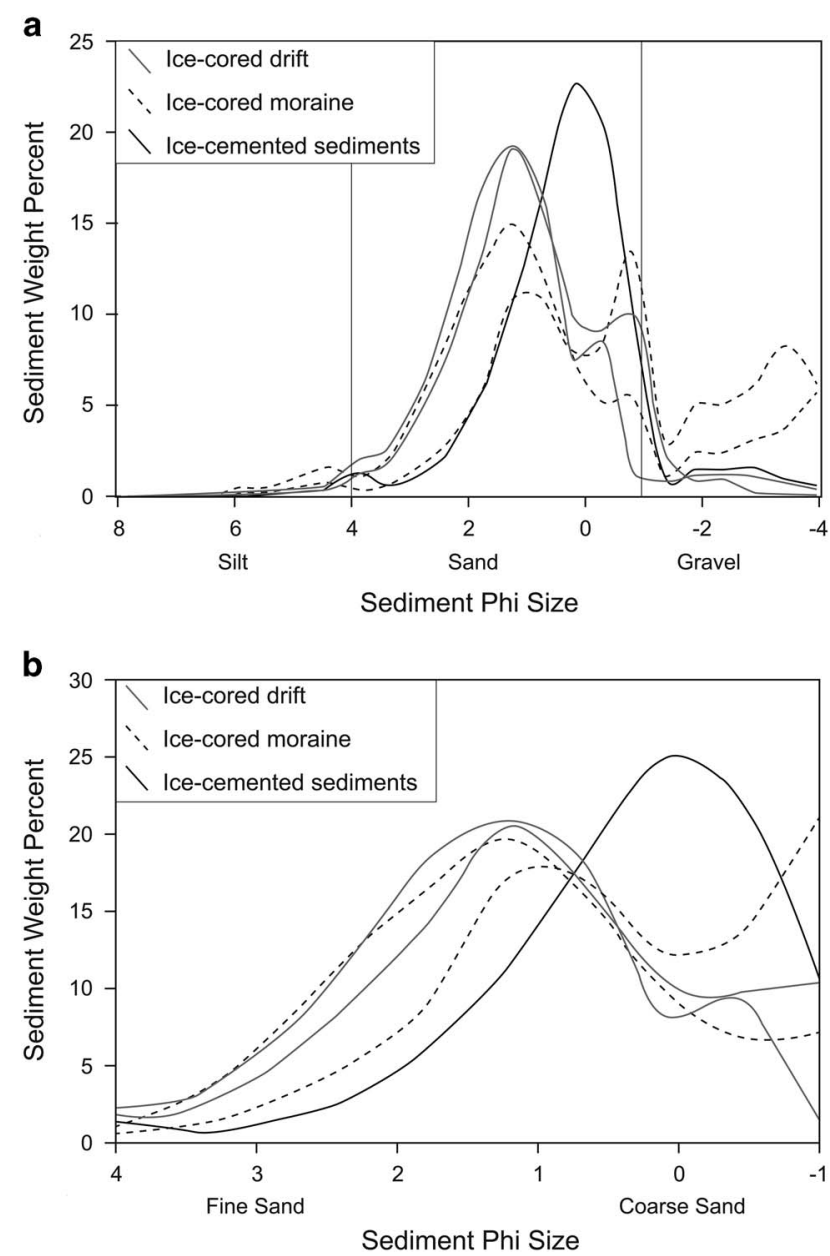

Fig. 3. Sediment distribution of the $<16 \mathrm{~mm}$ fraction in representative samples from the ice-cored drift (grey line), ice-cored moraines (dashed line) and ice-cemented sediments distal to the ice-cored deposits (black line). a. Distribution of all sediments $<16 \mathrm{~mm}$. Clays constitute $<0.5 \mathrm{wt} \%$ of all deposits and are not included on the graph. b. Distribution of sand fraction. Ice-cored moraines and drifts are classified as sand-supported, clast-rich tills. The material distal to the moraines is a coarse grained sand that is probably alluvium.

Based on present-day ice flow rates $\left(5-10 \mathrm{~m} \mathrm{yr}^{-1}\right)$ and the distance to Taylor Dome, the ice that presently occupies the mouth of Kennar Valley is $<10 \mathrm{ka}$. The relatively rapid transport of ice from Taylor Dome to Kennar Valley is supported by stable isotopic analyses and dating of ice farther downflow on Taylor Glacier. Glacier ice near the Cavendish Rocks (30 km downflow from Kennar Valley) is 10-20 ka. Ice near the present-day snout of Taylor Glacier is up to $120 \mathrm{ka}$ (Aciego et al. 2007, Buizert et al. 2014). Consequently, given present-day ice dynamics there is minimal time lag between snow deposition/ice formation at Taylor Dome and its transport to the Kennar Valley mouth. Additionally, supraglacial transport times for boulders would be $<10 \mathrm{kyr}$ and therefore pre-depositional exposure during
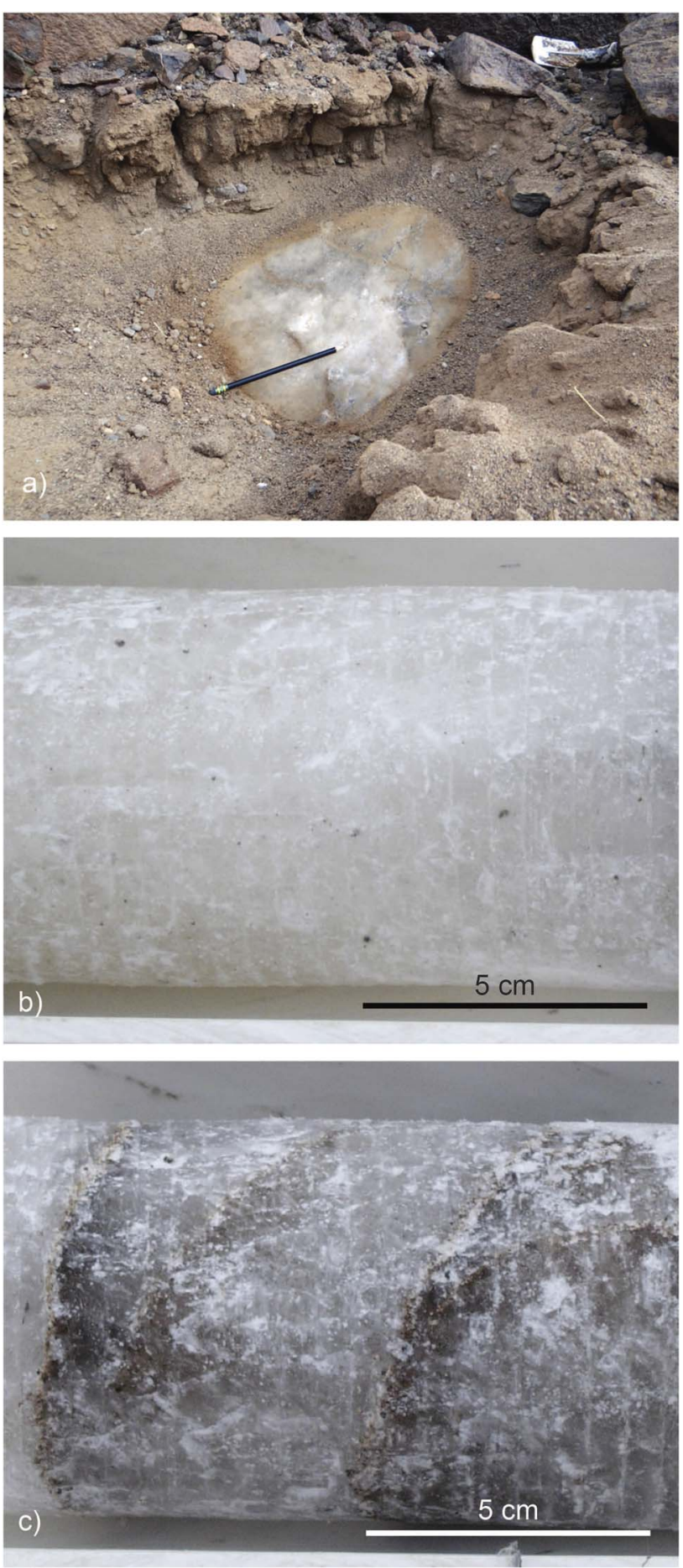

Fig. 4a. Clean ice surface at $25 \mathrm{~cm}$ depth from excavation 13-002 near cores DC-06-50 and -51. Note pencil for scale. b. Ice core DC-06-52, 40-50 cm depth, top of ice core is on the right. c. Ice core DC-06-52, 30-40 cm depth, top of ice core is on the right. b. \& c. show the range in sediment concentrations common across all three ice cores.

transport results in minimal errors when interpreting exposure ages from the Kennar Valley drifts and moraines. 
The chronology for all nine mapped drifts deposited by Taylor Glacier in Kennar Valley ranges from late Pleistocene to mid-Pliocene and comes from cosmogenic ${ }^{3} \mathrm{He}$ measured in 27 clasts of Ferrar Dolerite (Swanger et al. 2011). In general, the chronology indicates minor retreat of ice ( 200 vertical $\mathrm{m})$ since late Pliocene time. The Kennar Valley drifts can be subdivided into two types: ice-cored and non-icecored. Non-ice-cored moraines are common in upper Kennar Valley (not discussed here) and range in age from $\sim 400$ to $\sim 2400 \mathrm{ka}$ (Swanger et al. 2011). Icecored moraines and drifts only occur in lower Kennar Valley, directly adjacent to the present glacier and exhibit younger exposure ages (<300 ka) (Figs $1 \& 2)$. These lower Kennar Valley deposits include a complex network of ice-cored moraines, ice-cored drift with polygons and boulder-rich drop moraines (lacking ice cores) (Fig. 2). The cosmogenic data suggest that the moraines and ice-cored deposits in lower Kennar Valley range from 79-284 ka (Swanger et al. 2011), with eight of the 11 exposure ages centred at $\sim 120 \pm 30 \mathrm{ka}$ (Fig. 2).

\section{Methods}

\section{Ice core extraction and description}

Three shallow ice cores were extracted from buried glacier ice in lower Kennar Valley using a SIPRE auger, with a core diameter of $7.6 \mathrm{~cm}$. Two ice core locations were chosen based on their relative proximity to Taylor Glacier, ease of excavation and absence of large boulders in the ice. At location one, two ice cores were extracted (DC-06-50 and -51) measuring $148 \mathrm{~cm}$ and $110 \mathrm{~cm}$, respectively. At the second location, one ice core (DC-06-52) was extracted measuring $250 \mathrm{~cm}$. The depth of coring was limited by high sediment concentrations at the first site and by the equipment (hand auger) at the second site. Ice cores were extracted in subzero conditions and then kept frozen at $-20^{\circ} \mathrm{C}$ until analysed. Ice cores were cut and processed at Boston University. Air bubble concentrations and ice/sediment characteristics were documented visually during ice coring operations and in the lab.

\section{Stable isotopic analyses}

Stable isotopic analyses of the ice cores were conducted on an isotope ratio mass spectrometer at the Boston University Stable Isotope Laboratory. Analyses for $\delta^{18} \mathrm{O}$ were performed via $\mathrm{CO}_{2}$ equilibration and deuterium analyses were performed via pyrolysis using a GVI ChromeHD system. Analytical precision for both measurements is typically $\pm 0.1 \%$ o. Isotope values are presented as per mil (\%o) relative to the Vienna Standard
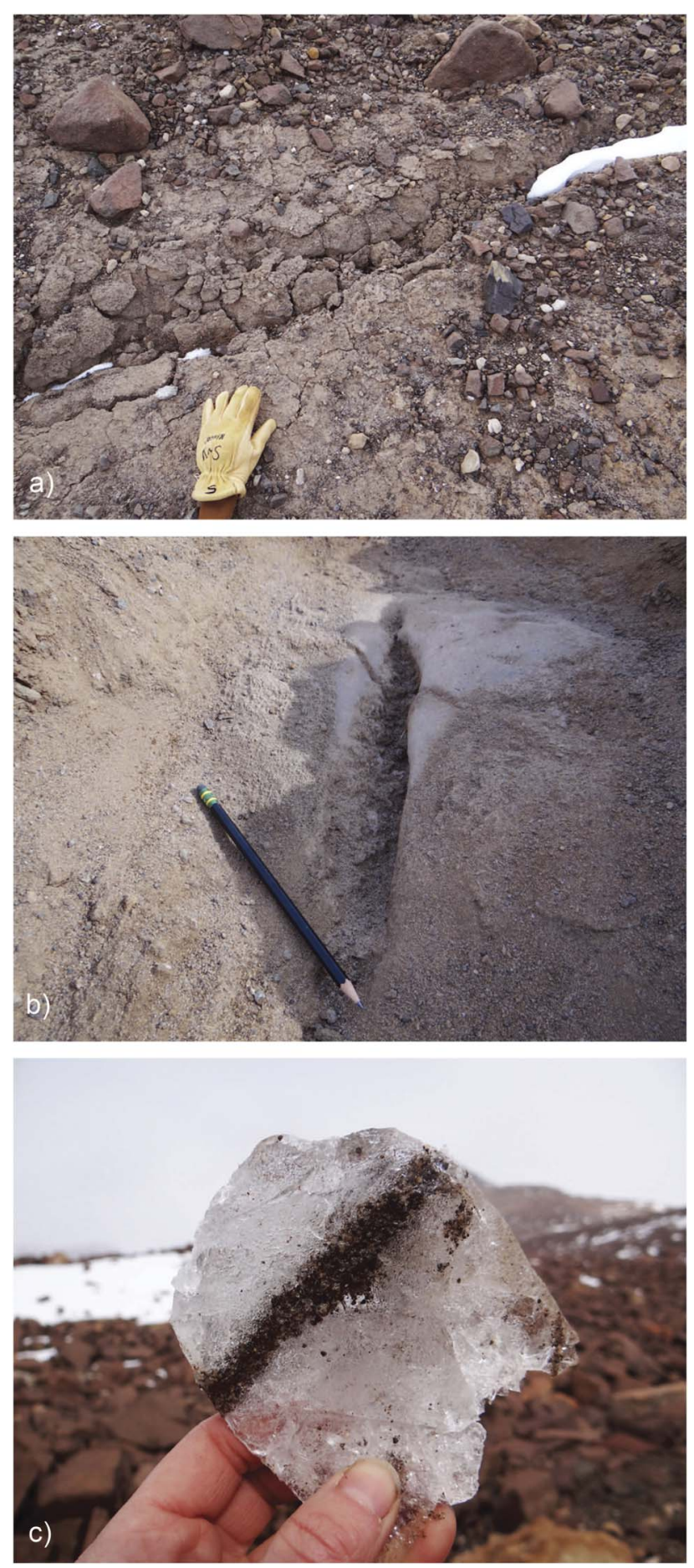

Fig. 5. Contraction-crack morphology and sedimentation at KSE-13-005 in ice-cored drift adjacent to clean ice cliff of Taylor Glacier. a. Unexcavated contraction crack at surface. Note fine sands falling into the crack. b. Buried ice surface $(<20 \mathrm{~cm}$ of drift) with contraction crack depression as ice is preferentially sublimated along the crack. c. Clean, bubblerich ice with $2 \mathrm{~cm}$ thick sand-rich vein. 

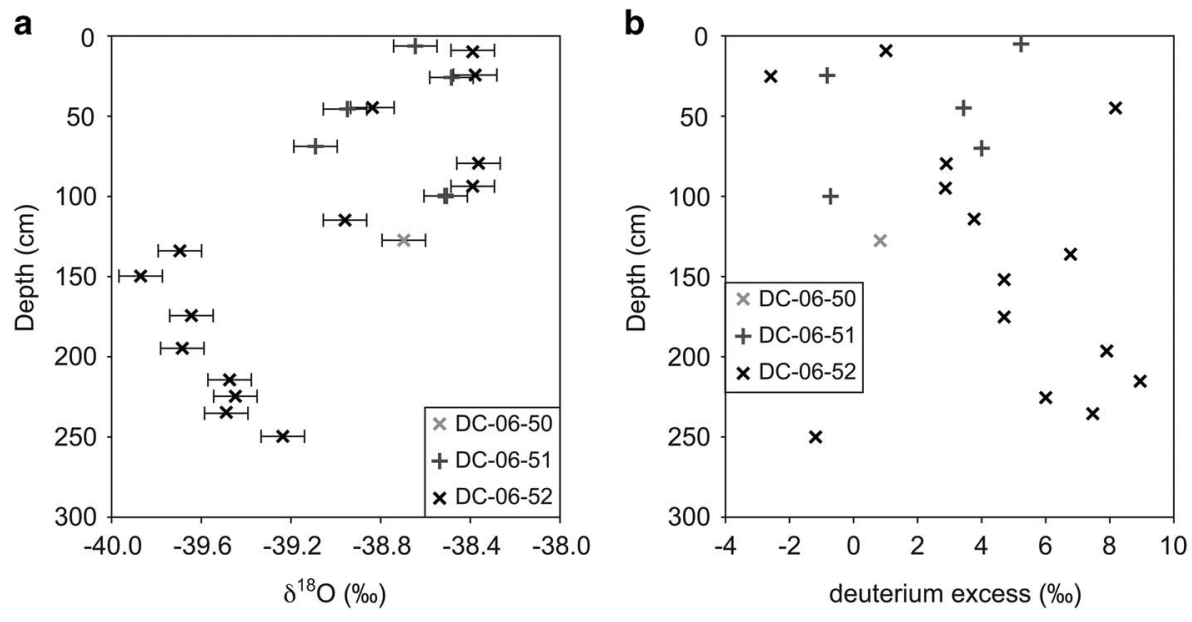

Fig. 6a. $\delta^{18} \mathrm{O}$ and b. deuterium excess $v s$ depth for ice from cores DC-06-50, -51 and -52 .
Mean Ocean Water (VSMOW). Deuterium excess (d) values were calculated as:

$$
d=\delta D-8 \delta^{18} O
$$

\section{Sediment and polygon characteristics}

The grain size distribution of debris that overlies buried glacier ice in lower Kennar Valley was determined using standard wet and dry sieving techniques. The $16-64 \mathrm{~mm}$ fraction was separated in the field and analysed for shape and lithology using Zingg classification. The $<16 \mathrm{~mm}$ fraction was wet sieved to determine the clay and silt fraction and then dry sieved at 0.5 phi intervals.

Polygon characteristics were mapped both in the field, using a tape and compass, and via satellite imagery. In satellite images (Worldview-2 Panchromatic with minimum resolution of $0.5 \mathrm{~m}$ ), the diameters of
700 polygons were measured in Kennar and Beacon valleys (100 randomly selected polygons at each site). North-south and east-west axes were measured for each polygon and then averaged. In Kennar Valley, polygons were measured in the ice-cored drift and the ice-cemented sediments immediately distal to the ice-cored moraine (Fig. 2). Polygon heights (the vertical change from polygon trough to crest) were measured in the field using a tape and compass, as well as from field observations and field photographs.

Polygons from five sites in Beacon Valley were measured for comparison with Kennar Valley sites. Locations were chosen based on the presence of buried ice, flow dynamics, drift characteristics and thickness of the ice. The first clean ice site, in central Mullins Glacier $\left(77^{\circ} 53^{\prime} 7.6^{\prime \prime} \mathrm{S}, 160^{\circ} 32^{\prime} 46^{\prime \prime} \mathrm{E}\right)$, was chosen because i) ice thickness is only $20-30 \mathrm{~m}$ (Mackay et al. 2014) and ii) the thickness of overlying sediments, $20-30 \mathrm{~cm}$

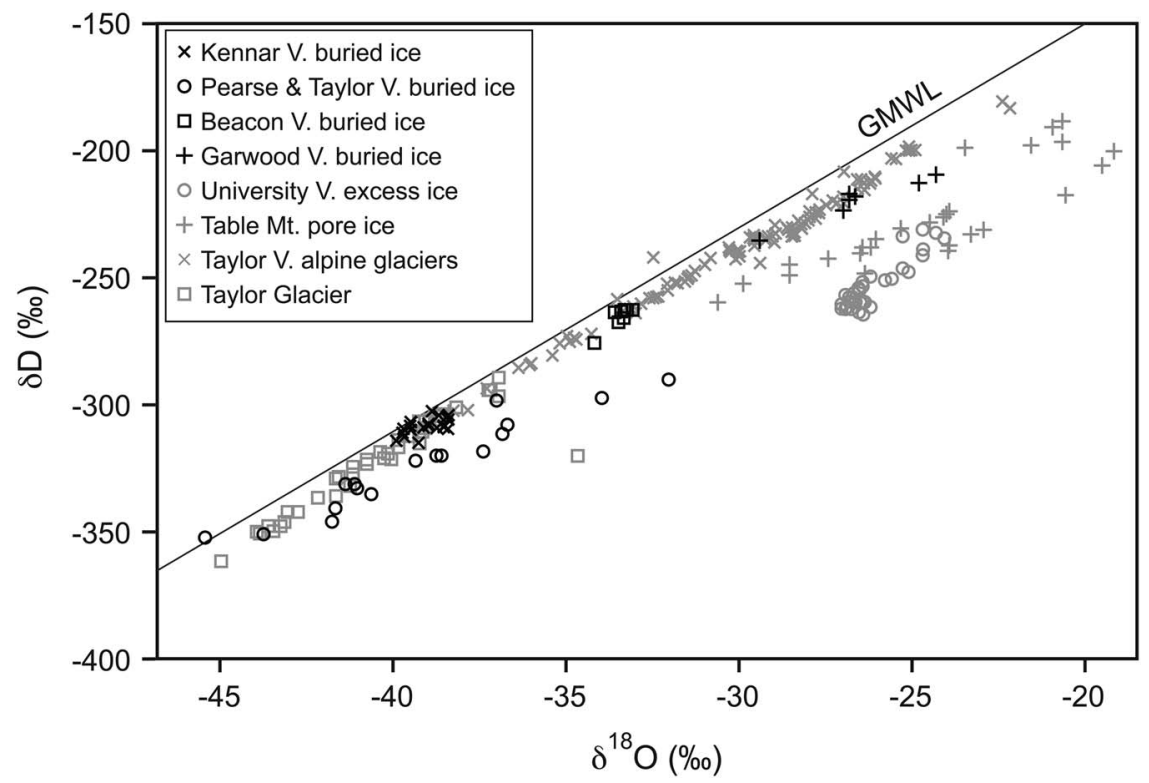

Fig. 7. Oxygen and hydrogen isotopic data for selected buried clean ice, excess ice, pore ice and glaciers in the McMurdo Dry Valleys. Excess ice refers to thin horizontal bands of ice in sediments as opposed to buried ice (thick deposits of clean ice) and pore ice (interstitial ice). Data sources: Taylor and alpine glaciers from Gooseff et al. (2006), Beacon Valley from Sugden et al. (1995), University Valley from Lacelle et al. (2013), Table Mountain from Dickinson \& Rosen (2003), Pearse and Taylor valleys from Swanger et al. (2010), Garwood Valley from Pollard et al. (2002) and Kennar Valley (this study). GMWL $=$ global meteoric water line. 

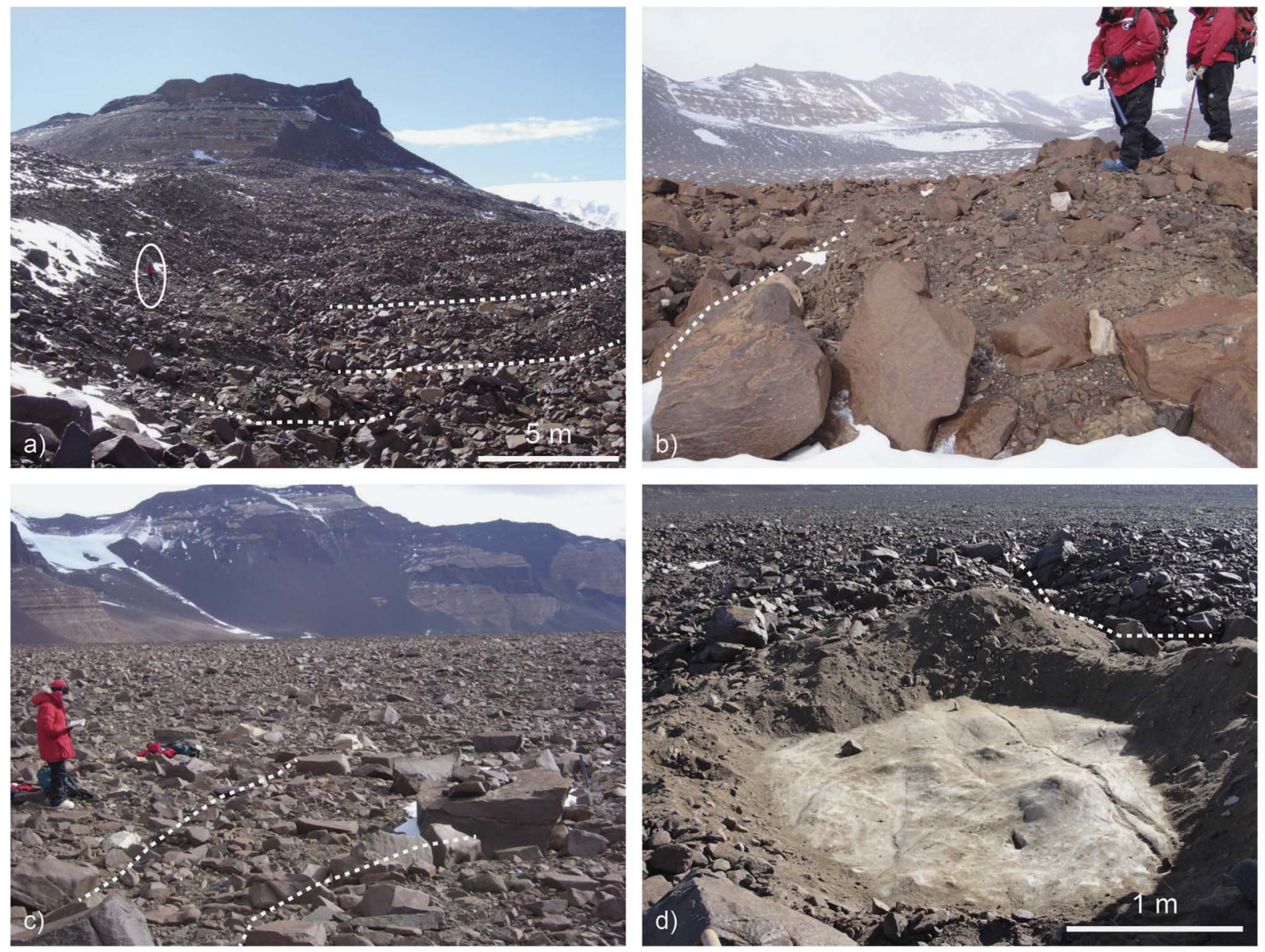

Fig. 8. Comparison of polygon morphology in Kennar, Beacon and Mullins valleys. Dashed lines highlight polygon troughs. a. Southwestern margin of the buried ice in Kennar Valley, bound by a bedrock slope that is overlain by a moraine. Person for scale (circled), moraine to the left and patterned ground to the right. b. Polygon trough (left) and crest (right) from Kennar Valley. Trough to crest height is $\sim 3 \mathrm{~m}$. c. Polygons in central Mullins Valley, sediment cover is $15-20 \mathrm{~cm}$ thick. d. Excavated buried glacier ice in south-western Beacon Valley. Note flat ice surface and polygon trough in the background.

(Kowalewski et al. 2011), is similar to conditions for buried ice in lower Kennar Valley. However, the Mullins ice is flowing at this location (Rignot et al. 2002), which affects polygon morphology (Levy et al. 2006). The second clean ice site, in central Beacon Valley (77'51'50"S, $\left.160^{\circ} 33^{\prime} 48^{\prime \prime} \mathrm{E}\right)$, exhibits stagnant ice, with ice thicknesses exceeding $80 \mathrm{~m}$ (Shean \& Marchant 2010) and sediment cover $>60 \mathrm{~cm}$ thick (Kowalewski et al. 2011). The third clean ice site is in upper University Valley, a cirque in south-eastern Beacon Valley $\left(77^{\circ} 52^{\prime} 10^{\prime \prime} \mathrm{S}, 160^{\circ}\right.$ $43^{\prime} 48$ "E). This site contains an $\sim 8 \mathrm{~m}$ thick buried glacier ice deposit overlain by $10-15 \mathrm{~cm}$ of rockslide material (Pollard et al. 2012). Ice flow conditions and the age of burial are unknown at this site; however, the buried ice is still geographically connected to the cirque glacier and is therefore probably flowing. There are no published data on polygon height at the University Valley, and the location was not visited for this study. The fourth and fifth sites are from ice-cemented sediments in Farnell and University valleys in Beacon Valley ( $77^{\circ} 52^{\prime} 45^{\prime \prime} \mathrm{S}, 160^{\circ}$ $40^{\prime} 15^{\prime \prime} \mathrm{E}$ and $77^{\circ} 51^{\prime} 48^{\prime \prime} \mathrm{S}, 160^{\circ} 42^{\prime} 30^{\prime \prime} \mathrm{E}$, respectively) (Fig. 1). Both sites have been previously analysed for relationships between depth to ice and polygon size (Marinova et al. 2013, Mellon et al. 2014). These sites act as a comparison for the polygons in ice-cemented sediments in lower Kennar Valley.

\section{Results}

\section{Sedimentology and morphology of lower Kennar Valley deposits}

Buried ice in lower Kennar Valley is consistently overlain by $20-35 \mathrm{~cm}$ of boulder-rich drift with a sandy 


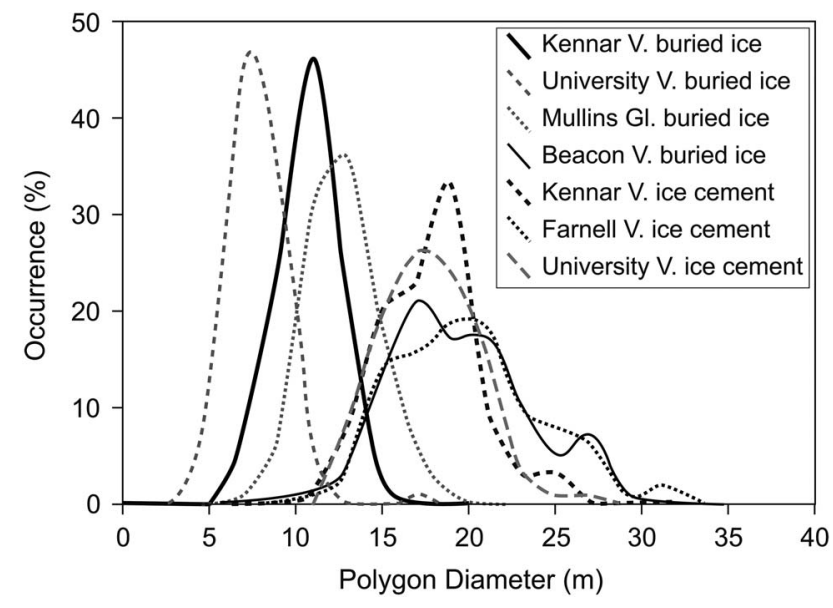

Fig. 9. Contraction-crack polygon diameters for buried glacier ice and ice-cemented ground in Kennar and Beacon valleys. Mullins, Farnell and University valleys are in south-eastern Beacon Valley. Data are based on measurements of 100 polygons at each location. Polygon diameter for buried ice deposits increases with increasing ice thickness and increasing sediment thickness. Polygon diameters in icecemented sediments are generally larger and increase with increasing depth to the ice table. See Table I for more information.

matrix (Fig. 3). Sediments are often weakly salt-cemented and exhibit minor evidence of near-surface oxidation and rubification. Clasts at the surface of the ice-cored drift are composed of Ferrar Dolerite (80-90\%), Feather Conglomerate, and undifferentiated sandstones, siltstones and shales. Boulders are commonly stacked and boulder concentrations are greater in polygon troughs due to gravitationally driven sliding. The clasts of dolerite are typically $\sim 1-2 \mathrm{~m}$ in diameter and exhibit weakly developed rock varnish $(<1 \mathrm{~mm}$ thick). A prominent ice-cored moraine circumscribes the $\sim 300 \mathrm{~m}^{2}$ region of buried ice in lower Kennar Valley (Fig. 2). This ice-cored moraine exhibits a thicker sediment cover, $>50 \mathrm{~cm}$ based on four field excavations. Sedimentology of the ice-cored moraine is similar to the ice-cored deposit: a boulder-rich drift with a sandy matrix (Fig. 3). Beyond the ice-cored moraine, the valley floor is covered by undifferentiated coarse sands. These deposits contain isolated boulders (clast frequency is lower than that on the moraines and ice-cored drifts), and do not exhibit any buried massive ice. Pore ice is present at depths of $\sim 25 \mathrm{~cm}$ directly south of the icecored moraine.

\section{Sedimentology and morphology of buried ice}

The ice-cored moraine in lower Kennar Valley rises $5-10 \mathrm{~m}$ above both the ice-cored drift and the undifferentiated sediments south of the ice-cored moraine. This suggests that the buried ice is $<10 \mathrm{~m}$ thick, unless it resides in a deep bedrock basin. The latter option is unlikely, based on the gently sloping topography in lower Kennar Valley, which transitions seamlessly from the region with buried ice to nonice-cored sediments beyond (Fig. 2). The ice-cored moraine is elevated above the surface of the ice-cored drift possibly because i) the ice-cored moraine is capped by a much thicker sediment cover ( $>50 \mathrm{~cm}$ compared to $25 \mathrm{~cm}$ ), which significantly decreases sublimation rates, and/or ii) the deposition of the moraine might post-date the deposition of the ice-cored drift. The latter scenario is possible due to the cold-based conditions for the Taylor Glacier lobe at this location, which greatly limits subglacial erosion. Boulder-rich drop moraines (Fig. 2) are stratigraphically younger than both the ice-cored drift and the ice-cored moraine, indicating that Taylor Glacier did advance over the ice-cored deposits at least once.

Data from three ice cores (DC-06-50, -51 and -52) collected from the buried ice (Fig. 2) show that it is heterogeneous, ranging from clean, bubble-rich ice with minor dispersed fines to ice containing multiple cross-cutting sand wedges (Fig. 4). Sediment concentrations in the ice range from $0-20 \%$ by volume. The lithological constituents that comprise the sand veins are similar to those in overlying drift, showing minor levels of rubification. Based on the sand vein morphology and the sedimentology of the overlying drift, these sandrich layers are interpreted to be gravitational infilling of contraction cracks (Fig. 5). Therefore, they are probably secondary sedimentological features and were probably not present prior to ice deposition in Kennar Valley. Dispersed fine grains (silt and clay, $<3 \%$ by volume) are present in one of the three ice cores (DC-06-50) and are interpreted to be windblown material. Except near sand veins, all ice contains air bubbles that are spherical and $<1 \mathrm{~mm}$ in diameter. Locally, ice without bubbles occurs in proximity to sand veins $(<5 \mathrm{~cm}$ distance), possibly indicating localized meltwater infiltration into contraction cracks.

\section{Stable isotopes in the Kennar Valley buried ice}

Ice was sampled at $10-20 \mathrm{~cm}$ intervals in the ice cores (variation in sampling interval was due to the presence and location of sediment-rich layers that could not be sampled). Oxygen and hydrogen isotopes ( $\delta^{18} \mathrm{O}$ and $\left.\delta \mathrm{D}\right)$ were remarkably similar between all three cores, ranging from $-40--38 \%$ and $-302--316 \%$, respectively (Fig. 6). The Kennar Valley ice is isotopically light compared to buried ice sampled in Beacon Valley (Fig. 7). In all ice cores, there is a general trend toward more negative $\delta^{18} \mathrm{O}$ values and more positive deuterium excess values with depth. However, the samples from all three ice cores fall in a very narrow isotopic range, making interpretations of these general trends dubious. Isotopically, Kennar Valley buried 
Table I. Comparison of polygon morphology in Kennar and Beacon valleys.

\begin{tabular}{|c|c|c|c|c|c|c|c|c|c|}
\hline & Latitude (S) & Longitude (E) & Type of ice & $\begin{array}{l}\text { Ice flow } \\
\text { dynamics }\end{array}$ & $\begin{array}{l}\text { Inferred } \\
\text { ice age }\end{array}$ & $\begin{array}{l}\text { Average depth } \\
\text { to ice }\end{array}$ & $\begin{array}{l}\text { Clean ice } \\
\text { thickness }\end{array}$ & $\begin{array}{l}\text { Polygon } \\
\text { diameter }^{\mathrm{d}}\end{array}$ & $\begin{array}{l}\text { Polygon } \\
\text { height }^{\mathrm{d}}\end{array}$ \\
\hline Kennar Valley & $77^{\circ} 45^{\prime} 05^{\prime \prime}$ & $160^{\circ} 25^{\prime} 20^{\prime \prime}$ & Buried glacier & Stagnant & $<300 \mathrm{ka}$ & $25 \mathrm{~cm}$ & $<10 \mathrm{~m}$ & $11 \pm 2 \mathrm{~m}$ & $2-3 m$ \\
\hline Mullins Glacier ${ }^{\mathrm{e}}$ & $77^{\circ} 53^{\prime} 08^{\prime \prime}$ & $160^{\circ} 32^{\prime} 46^{\prime \prime}$ & Buried glacier & Flowing Glacier & $<500 \mathrm{ka}$ & $25 \mathrm{~cm}$ & $20-30 \mathrm{~m}$ & $13 \pm 2 \mathrm{~m}$ & $<1 \mathrm{~m}$ \\
\hline Beacon Valley & $77^{\circ} 51^{\prime} 50^{\prime \prime}$ & $160^{\circ} 33^{\prime} 48^{\prime \prime}$ & Buried glacier & Stagnant & $>1.5 \mathrm{Ma}$ & $60-100 \mathrm{~cm}$ & $>80 \mathrm{~m}$ & $20 \pm 5 \mathrm{~m}$ & $1-3 \mathrm{~m}$ \\
\hline University Valley $^{\mathrm{e}}$ & $77^{\circ} 52^{\prime} 10^{\prime \prime}$ & $160^{\circ} 43^{\prime} 48^{\prime \prime}$ & Buried glacier & Active Glacier & Recent & $10 \mathrm{~cm}$ & $5-6 \mathrm{~m}$ & $8 \pm 2 \mathrm{~m}$ & Unknown \\
\hline Kennar Valley ${ }^{\mathrm{e}}$ & $77^{\circ} 45^{\prime} 16^{\prime \prime}$ & $160^{\circ} 24^{\prime} 55^{\prime \prime}$ & Pore ice & Stagnant & N/A & $25 \mathrm{~cm}$ & N/A & $18 \pm 3 \mathrm{~m}$ & $<30 \mathrm{~cm}$ \\
\hline University Valley $^{\mathrm{e}}$ & $77^{\circ} 51^{\prime} 48^{\prime \prime}$ & $160^{\circ} 42^{\prime} 30^{\prime \prime}$ & Pore ice & Stagnant & N/A & $30 \mathrm{~cm}$ & N/A & $18 \pm 3 \mathrm{~m}$ & $<30 \mathrm{~cm}$ \\
\hline
\end{tabular}

${ }^{a}$ Active glacier = ice flow rates unknown, flowing glacier = ice flow rates measured (Rignot et al. 2002), stagnant = non-flowing ice.

${ }^{\mathrm{b}}$ Ages of the buried glacier ice from: Kennar Valley (Swanger et al. 2011), Mullins Glacier (Marchant et al. 2007, Mackay et al. 2014), and central Beacon Valley (Yau et al. 2015).

${ }^{c}$ Ice thickness data for Mullins Glacier and Beacon Valley from Shean \& Marchant (2010) and Mackay et al. (2014). Depth to ice for Mullins Glacier and Beacon Valley from Kowalewski et al. (2011).

${ }^{\mathrm{d}}$ See Methods.

${ }^{\mathrm{e}} \mathrm{See}$ Fig. 1 for locations.

ice plots on the local meteoric water line (LMWL) and within the range of ice sampled from Taylor Dome and Taylor Glacier, supporting a glacial source for this ice body.

\section{Polygon morphology in Kennar and Beacon valleys}

The polygons in Kennar Valley are distinctive among most polygons in the Quartermain Range, in both size and shape (Fig. 8). They are significantly smaller $(11 \pm 2 \mathrm{~m})$ than the majority of the polygons in debris-covered ice in Beacon Valley $(20 \pm 5 \mathrm{~m})$ (Fig. 9). They also exhibit a very pronounced dome shape in profile, rather than the more common flat-topped polygons found in Beacon Valley. These differences may be due to the relative thicknesses of the ice and the overlying sediment cover at the two locations. Central Beacon Valley contains a thick ( $>80 \mathrm{~m}$ ) glacial ice body with an overlying sublimation till that is also thick ( $>60 \mathrm{~cm}$ ). Conversely, the buried glacier ice in Kennar Valley is inferred to be $<10 \mathrm{~m}$ thick and it is consistently overlain by only $20-35 \mathrm{~cm}$ of sand-rich drift. Given that the depth to ice in Kennar Valley is much shallower than that in central Beacon Valley, thermally induced tensile stresses in the winter are probably greater and, as a result, the polygons are smaller.

Notably, small diameter polygons are found in two locations in south-eastern Beacon Valley that contain thin buried ice deposits: on central Mullins (debris-covered) Glacier and on a small cirque glacier in University Valley. At both locations a thin sediment cover $(10-30 \mathrm{~cm})$ overlies relatively thin ice deposits, $20-30 \mathrm{~m}$ and $7-9 \mathrm{~m}$, respectively (see Table I for data and citations). These two locations exhibit similar morphologic conditions to those in lower Kennar Valley. However, the Mullins Glacier polygons do not exhibit deep troughs or pinnacle shapes in profile (Figs $8 \& 9$, Table I). This is presumably due to the fact that the Mullins ice is flowing and lateral stresses are preventing the formation of deep troughs. Conversely, the buried ice in Kennar Valley is stagnant. There is currently insufficient information on polygon heights in University Valley for comparison.

\section{Discussion}

\section{Stable isotopes in the McMurdo Dry Valleys}

Stable isotopic measurements from ice, snow and water in the MDV have primarily been conducted by the LongTerm Ecological Research (LTER) team with the primary focus on Taylor Valley alpine glaciers, streams and lakes. In the MDV, the stable isotopic signature of alpine and outlet glacier ice falls on a LMWL of 7.8 (Gooseff $e t$ al. 2006). The main precipitation source for MDV glaciers is snow sourced from the Ross Embayment during the sea ice-free summer months (Fountain et al. 2009). There is a direct relationship between equilibrium line altitude and distance from the coast for alpine glaciers (Fountain et al. 2006). As a consequence, alpine glacier ice becomes isotopically lighter inland from the coast. Taylor Dome and Taylor Glacier follow this trend (Fig. 7).

In the 1990s, a $554 \mathrm{~m}$ long core was extracted from Taylor Dome, extending to an age of $\sim 160 \mathrm{kyr}$ at its base (Steig et al. 2000, Grootes et al. 2001). During warmer intervals (Marine Isotope Stages (MIS) 5, 3 and the early Holocene), $\delta^{18} \mathrm{O}$ at Taylor Dome ranged from $-37-$ $-40 \%$, and during colder intervals (MIS 6, 4 and 2), $\delta^{18} \mathrm{O}$ ranged from $-43--45 \%$ (Steig et al. 2000). Stable isotope variations at Taylor Dome correlate closely with air temperature fluctuations, and compared to the Holocene, precipitation rates at Taylor Dome decreased during the LGM (Grootes et al. 2001).

In addition to the comprehensive dataset on glaciers, there have been isolated investigations of stable isotopes in buried ice (both massive and interstitial), including upper Taylor and Pearse valleys (Swanger et al. 2010, Heldmann et al. 2012), Beacon Valley (Sugden et al. 
1995), Garwood Valley (Pollard et al. 2002, Levy et al. 2013), University Valley (Lacelle et al. 2013), Table Mountain (Dickinson \& Rosen 2003) and Victoria Valley (Hagedorn et al. 2010). These investigations demonstrate that buried ice throughout the MDV varies isotopically based on the source of the moisture (snowfall, meltwater, vapour diffusion, etc.) and with distance from the coast (Fig. 7). Stable isotopes from buried glacier ice, such as that in Beacon and Kennar valleys, fall on the LMWL. Buried massive ice in warmer locations, such as Pearse and Garwood valleys (Fig. 1), falls below the LMWL due to evaporation. Interstitial (pore) ice is isotopically complex based on local climate, moisture source and age (Dickinson \& Rosen 2003, Hagedorn et al. 2010, Lacelle et al. 2013).

\section{Origin and age of Kennar Valley buried ice}

The isotopic signature of the buried ice in Kennar Valley falls within a narrow range, despite being sampled from different morphologic regions of the ice body (see Fig. 2 for ice core locations). This probably indicates a sole source for the entire ice deposit. As previously mentioned, oxygen and hydrogen isotopes fall on the LMWL, indicating a glacial origin with minimal melting/ refreezing and evaporation. More specifically, the Kennar Valley buried ice lies within the isotopic range of Taylor Dome during interglacial intervals (Fig. 7).

Based on the isotopic signature of the buried ice and the exposure age distribution of the samples from the overlying drift, the ice probably represents an advance of Taylor Glacier during a late Pleistocene interglacial interval. Additional evidence for advance comes from central Taylor Valley, where mapped and dated drifts indicate that during MIS 5 Taylor Glacier was $\sim 200 \mathrm{~m}$ higher in elevation than present (Higgins et al. 2000). Also, ${ }^{3} \mathrm{He}$ and

${ }^{10} \mathrm{Be}$ exposure ages from moraines in Arena Valley (in the Quartermain Range) show multiple advances of Taylor Glacier (200-325 m higher in elevation at this location) during the late Pleistocene (Brook et al. 1993, Marchant et al. 1994). Due to ice flow dynamics near Kennar Valley, advances of Taylor Glacier in this region are significantly less in terms of vertical ice changes (Kavanaugh et al. 2009a, Swanger et al. 2011). These muted vertical ice fluctuations, along with the flat topography in lower Kennar Valley, allowed for the deposition of the stagnant ice body during advance.

\section{Polygon morphology and ice thickness}

Mellon et al. (2014) demonstrated that polygon diameter varies directly with the depth to the ice table in ice-cemented sediments in the Quartermain Range. The dry sediments above the ice table act as a thermal buffer, resulting in decreased tensile stress in the ice-cemented sediments during the winter months. As a result, sediments with deeper ice tables tend to have larger polygons, with wider spacing between contraction cracks. However, the relationship between ice depth and polygon size for buried glacier ice is more complex. Assuming pure-ice rheology and applying tensile stresses based on winter temperatures, polygons are much smaller (closer spacing between contraction cracks) than would be expected for the observed depth to the clean ice boundary (Mellon et al. 2014).

Marchant \& Head (2007) noted that ice-cemented permafrost and debris-covered glacier ice develop distinctive polygon morphologies, thereby demonstrating that polygons could be used to map ground-ice properties. For example, deep polygon troughs occur only when contraction cracks form in clean buried ice. Additionally, polygon morphology has been used throughout the Antarctic to infer the flow properties of subsurface ice. For example, Levy et al. (2006) mapped polygon surface morphologies and degree of deformation to quantify flow of debris-covered glaciers in Beacon Valley. Taken together, these studies indicate the possibility of using contraction-crack and polygon morphology in the MDV to infer the presence, depth and flow dynamics of subsurface ice.

As noted previously, the polygons in lower Kennar Valley are morphologically distinct compared to many of the polygons in nearby Beacon Valley. Small diameter polygons do occur in Mullins and University valleys where buried glacier ice is active, thin $(10-30 \mathrm{~m})$ and covered by $<30 \mathrm{~cm}$ of sediment. When comparing the four buried ice sites in Kennar and Beacon valleys, there is a clear relationship between polygon diameter and clean ice thickness (Fig. 9, Table I). University Valley contains only 7-9 $\mathrm{m}$ of ice and has the smallest diameter polygons $(8 \pm 2 \mathrm{~m})$ compared to central Beacon Valley that contains $>80 \mathrm{~m}$ of ice and has large polygons $(20 \pm 5 \mathrm{~m})$. The Mullins and Kennar sites fall between these two endmembers.

However, polygon heights in Kennar Valley are anomalously high relative to polygon diameter. This results in a unique dome-shaped morphology that is probably a product of sublimation of a thin, stagnant ice body. Although contraction cracks are still forming during the winter months, the cracks are isolated (Figs $4 \& 5$ ), and it appears that a new contractioncrack network does not form. As a consequence, the extant closely spaced troughs continue to deepen, resulting in isolated dome-shaped ice pinnacles (with anomalously deep troughs) that are downwasting in place. This gives the patterned ground a distinct morphology compared to thick ice bodies, such as those in central Beacon Valley and thin flowing ice bodies, such as those in central Mullins Glacier and upper University Valley (Figs 8 \& 9, Table I). 
Building on previous studies regarding polygon morphology and its relationship to ice flow and ice table depth (Levy et al. 2006, Mellon et al. 2014), the data presented here demonstrate that polygon morphologies might also be used to assess the relative thickness of the underlying ice, especially for stagnant ice bodies. The small pinnacle-shaped polygons in Kennar Valley are probably forming during the final stages of stagnant ice sublimation. As the thickness of the buried ice decreases, the sublimating ice passes a threshold after which a new, spatially extensive contraction-crack network does not form. Based on the polygon morphologies in Kennar and Beacon valleys, this occurs when ice thickness is $<10-20 \mathrm{~m}$.

\section{The relative stability of buried ice in the Quartermain Range}

The exposure ages, patterned ground morphology and stable isotopic analyses all indicate that the buried ice in lower Kennar Valley was deposited by a late Pleistocene advance of Taylor Glacier during an interglacial interval. If the overlying sediments were deposited as a sublimation till (rather than a talus rockslide or a mixed cold-based drift), the thickness of the overlying drift would have been thinner (or even non-existent) when the ice was deposited. However, due to the sublimation rates for exposed ice in this region, $10-15 \mathrm{~cm} \mathrm{yr}^{-1}$ (Bliss et al. 2011), a sublimation till could form quickly on top of ice with even small amounts of englacial debris. Once the sublimation till is $>10 \mathrm{~cm}$, sublimation rates for the underlying ice are significantly reduced allowing for long-term ice preservation (Kowalewski et al. 2011).

Regardless of the origin of the sediment that caps the buried ice in lower Kennar Valley (sublimation till vs a mixed cold-based drift), the sediment cover now helps to protect the ice from rapid sublimation. Based on i) atmospheric temperatures and relative humidity at Kennar Valley, ii) the thickness of the sediment cover $(25 \mathrm{~cm})$ and iii) sublimation models from Beacon Valley, sublimation rates for the lower Kennar Valley ice are $\sim 1.5 \times 10^{-4} \mathrm{~m} \mathrm{yr}^{-1}$ (Kowalewski et al. 2011). Assuming constant and continuous sublimation, the buried ice could disappear entirely in $<10^{5}$ years. Sublimation rates for buried ice are not constant or continuous and instead decrease with i) lower atmospheric temperatures, ii) higher relative humidity and iii) increasing thickness of sediment cover. However, realistic variations in atmospheric temperatures and relative humidity $\left(10^{\circ} \mathrm{C}\right.$ and 40\%) during glacial-interglacial cycles cause sublimation rates for buried ice to decrease by only 10-50\% (Kowalewski et al. 2011). Therefore, even with future climate variations, the Kennar Valley ice is relatively unstable compared to the multimillion-year ice in Beacon Valley. These data highlight the exceptional conditions (such as relatively rapid deposition of a thick sublimation till and a thick initial ice body) that are necessary to preserve ice for millions of years, even in a cold desert such as the Quartermain Range.

\section{Conclusions}

Stagnant buried glacial ice occupies $\sim 300 \mathrm{~m}^{2}$ in lower Kennar Valley. A $20-35 \mathrm{~cm}$ thick sand-rich drift overlies the stagnant glacier ice with an abrupt contact between the clean buried ice and the dry sediments above. In some locations a thin $(<5 \mathrm{~cm})$ layer of ice cement exists at the ice-sediment boundary.

The ice-cored drift is part of a complex network of icecored drift, ice-cored moraines and drop moraines that were previously dated, via cosmogenic ${ }^{3} \mathrm{He}$ from dolerite boulders, to $80-300 \mathrm{ka}$. Age scatter is presumably due to complex exposure histories (advance of a cold-based Taylor Glacier over the drift), temporal and spatial variations in the formation/deposition of the ice-cored drift and/or disturbance of clasts by polygon development. Based on the previously published exposure age chronology and the stable isotopic analyses of ice from three shallow cores, the buried ice was deposited by an advance of Taylor Glacier during a late Pleistocene interglacial interval.

The ice-cored drift is polygonized due to the development of contraction cracks, which widen with time because of enhanced sublimation and sediment infill. The polygons in Kennar Valley are distinctive from most polygons in the Quartermain Range. Kennar polygons are small in diameter $(\sim 10 \mathrm{~m})$ and high-centred (domed) in cross-section, rather than flat-topped like the central Beacon Valley polygons. Small diameter polygons are found at only a few locations in Beacon Valley (specifically in University and Mullins valleys) where thin buried clean ice is capped by thin sediment cover. Polygon diameter appears to be related to the thickness of the buried clean ice and the thickness of the sediment cover. The distinctive small, dome-shaped polygons in lower Kennar Valley are probably in their final stage of development. As the ice in each polygon becomes physically disconnected from the ice in the surrounding polygons, this prevents the development of a new, connected contraction-crack network. As a consequence the ice pinnacles continue to sublimate in place, enhancing the dome-shaped morphology. Based on these data, polygon morphology might be used to infer the thickness and geomorphological stability of buried ice throughout Antarctica and other cold, arid regions such as Mars.

\section{Acknowledgements}

Thank you to Douglas Kowalewski, David Shean, Rebecca Parsons, James Head III, Christopher Ford and Andrew Christ for assistance in the field. Thank you 
to Robert Michener for conducting the stable isotope analyses at the Boston University Stable Isotope Laboratory. Thank you to David Marchant for insightful comments and edits on an earlier draft of this paper. Thank you to Warren Dickinson and one anonymous reviewer for helpful comments that increased the quality and accuracy of the manuscript; also thank you to the editors who handled this manuscript. All photographs were taken by Kate M. Swanger and reprinted with permission. The image in Fig. 1 is a public domain Landsat7 image courtesy of NASA Goddard Space Flight Center and US Geological Survey. Funding for this research was provided by NSF Division of Polar Programs Grants PLR-1043724 and PLR-1341284 to KMS. The author declares no competing financial interests.

\section{Author contribution}

KMS designed the research, analysed and synthesized the data, wrote the text and created all figures.

\section{References}

Aciego, S.M., Cuffey, K.M., Kavanaugh, J.L., Morse, D.L. \& Severinghaus, J.P. 2007. Pleistocene ice and paleo-strain rates at Taylor Glacier, Antarctica. Quaternary Research, 68, 10.1016/ j.yqres.2007.07.013.

Bliss, A.K., Cuffey, K.M. \& Kavanaugh, J.L. 2011. Sublimation and surface energy budget of Taylor Glacier, Antarctica. Journal of Glaciology, 57, 684-696.

Brook, E.J., Kurz, M.D., Ackert, R.P., Denton, G.H., Brown, E.T., Raisbeck, G.M. \& Yiou, F. 1993. Chronology of Taylor Glacier advances in Arena Valley, Antarctica, using in situ cosmogenic ${ }^{3} \mathrm{He}$ and ${ }^{10} \mathrm{Be}$. Quaternary Research, 39, 11-23.

Buizert, C., Baggenstos, D., Jiang, W., Purtschert, R., Petrenko, V.V., Lu, Z.T., Muller, P., Kuhl, T., Lee, J., Severinghaus, J.P. \& Brook, E.J. 2014. Radiometric ${ }^{81} \mathrm{Kr}$ dating identifies 120,000 -year-old ice at Taylor Glacier, Antarctica. Proceedings of the National Academy of Sciences of the United States of America, 111, 10.1073/ pnas. 1320329111.

Dickinson, W.W. \& Rosen, M.R. 2003. Antarctic permafrost: an analogue for water and diagenetic minerals on Mars. Geology, 31, 199-202.

Doran, P.T., McKay, C.P., Clow, G.D., Dana, G.L., Fountain, A.G., Nylen, T. \& Lyons, W.B. 2002. Valley floor climate observations from the McMurdo Dry Valleys, Antarctica, 1986-2000. Journal Geophysical Research - Atmospheres, 107, 10.1029/2001JD002045.

Elliot, D.H. \& Fleming, T.H. 2004. Occurrence and dispersal of magmas in the Jurassic Ferrar Large Igneous Province, Antarctica. Gondwana Research, 7, 223-237.

Fountain, A.G., Nylen, T.H., MacClune, K.L. \& Dana, G.L. 2006. Glacier mass balances (1993-2001), Taylor Valley, McMurdo Dry Valleys, Antarctica. Journal of Glaciology, 52, 451-462.

Fountain, A.G., Nylen, T.H., Monaghan, A., Basagic, H.J. \& Bromwich, D. 2009. Snow in the McMurdo Dry Valleys, Antarctica. International Journal of Climatology, 30, 10.1002/joc.1933.

Gooseff, M.N., Lyons, W.B., McKnight, D.M., Vaughn, B.H., Fountain, A.G. \& Dowling, C. 2006. A stable isotopic investigation of a polar desert hydrologic system, McMurdo Dry Valleys, Antarctica. Arctic Antarctic and Alpine Research, 38, 60-71.
Grootes, P.M., Steig, E.J., Stuiver, M., Waddington, E.D. \& Morse, D.L. 2001. The Taylor Dome Antarctic ${ }^{18} \mathrm{O}$ record and globally synchronous changes in climate. Quaternary Research, 56, 289-298.

Hagedorn, B., Sletten, R.S., Hallet, B., McTigue, D.F. \& Steig, E.J. 2010. Ground ice recharge via brine transport in frozen soils of Victoria Valley, Antarctica: insights from modeling $\delta^{18} \mathrm{O}$ and $\delta \mathrm{D}$ profiles. Geochimica et Cosmochimica Acta, 74, 435-448.

Heldmann, J.L., Marinova, M., Williams, K.E., Lacelle, D., Mckay, C.P., Davila, A., Pollard, W. \& Andersen, D.T. 2012. Formation and evolution of buried snowpack deposits in Pearse Valley, Antarctica, and implications for Mars. Antarctic Science, 24, 299-316.

Higgins, S.M., Hendy, C.H. \& Denton, G.H. 2000. Geochronology of Bonney Drift, Taylor Valley, Antarctica: evidence for interglacial expansions of Taylor Glacier. Geografiska Annaler, 82A, 391-409.

Kavanaugh, J.L., Cuffey, K.M., Morse, D.L., Bliss, A.K. \& Aciego, S. M. 2009a. Dynamics and mass balance of Taylor Glacier, Antarctica: 3. State of mass balance. Journal of Geophysical Research - Earth Surface, 114, 10.1029/2009JF001331.

Kavanaugh, J.L., Cuffey, K.M., Morse, D.L., Conway, H. \& Rignot, E. 2009b. Dynamics and mass balance of Taylor Glacier, Antarctica: 1. Geometry and surface velocities. Journal of Geophysical Research - Earth Surface, 114, 10.1029/2009JF001309.

Kowalewski, D.E., Marchant, D.R., Swanger, K.M. \& HEAD III, J.W. 2011. Modeling vapor diffusion within cold and dry supraglacial tills of Antarctica: implication for the preservation of ancient ice. Geomorphology, 126, 10.1016/j.geomorph.2010.11.001.

Lacelle, D., Davila, A.F., Fisher, D., Pollard, W.H., DeWitt, R., Heldmann, J., Marinova, M.M. \& McKay, C.P. 2013. Excess ground ice of condensation-diffusion origin in University Valley, Dry Valleys of Antarctica: evidence from isotope geochemistry and numerical modeling. Geochimica et Cosmochimica Acta, 120, 280-297.

Levy, J. 2013. How big are the McMurdo Dry Valleys? Estimating icefree area using Landsat image data. Antarctic Science, 25, 119-120.

Levy, J.S., Marchant, D.R. \& Head III, J.W. 2006. Distribution and origin of patterned ground on Mullins Valley debris-covered glacier, Antarctica: the roles of ice flow and sublimation. Antarctic Science, 18, 385-397.

Levy, J.S., Fountain, A.G., Dickson, J.L., Head, J.W., Okal, M., Marchant, D.R. \& Watters, J. 2013. Accelerated thermokarst formation in the McMurdo Dry Valleys, Antarctica. Scientific Reports, 3, 10.1038/srep02269.

Mackay, S.L., Marchant, D.R., Lamp, J.L. \& Head, J.W. 2014. Cold-based debris-covered glaciers: evaluating their potential as climate archives through studies of ground-penetrating radar and surface morphology. Journal of Geophysical Research - Earth Surface, 119, 2505-2540.

Marchant, D.R. \& HeAd III, J.W. 2007. Antarctic dry valleys: microclimate zonation, variable geomorphic processes, and implications for assessing climate change on Mars. Icarus, 192, 187-222.

Marchant, D.R., Denton, G.H., Bockheim, J.G., Wilson, S.C. \& KERR, A.R. 1994. Quaternary changes in level of the upper Taylor Glacier, Antarctica: implications for paleoclimate and East Antarctic Ice Sheet dynamics. Boreas, 23, 29-43.

Marchant, D.R., Lewis, A.R., Phillips, W.M., Moore, E.J., Souchez, R.A., Denton, G.H., Sugden, D.E., Potter, N. \& LANDIS, G.P. 2002. Formation of patterned ground and sublimation till over Miocene glacier ice in Beacon Valley, southern Victoria Land, Antarctica. Geological Society of America Bulletin, 114, 718-730.

Marchant, D.R., Phillips, W.M., Schaefer, J.M., Winckler, G., Fastook, J.L., Shean, D.E., Kowalewski, D.E., Head III, J.W. \& LEwIS, A.R. 2007. Establishing a chronology for the world's oldest glacier ice. 10th International Symposium on Antarctic Earth Sciences. Santa Barbara, CA: The National Academies Press. 
Marinova, M.M., McKay, C.P., Pollard, W.H., Heldmann, J.L., Davila, A.F., Andersen, D.T., Jackson, W.A., Lacelle, D., Paulsen, G. \& ZACNY, K. 2013. Distribution of depth to icecemented soils in the high-elevation Quartermain Mountains, McMurdo Dry Valleys, Antarctica. Antarctic Science, 25, 575-582.

McElroy, C.T. \& Rose, G. 1987. Geology of the Beacon Heights area southern Victoria Land Antarctica. Miscellaneous Series Map 15. Lower Hutt: Department of Scientific and Industrial Research, New Zealand Geological Survey.

McKay, C.P. 2009. Snow recurrence sets the depth of dry permafrost at high elevations in the McMurdo Dry Valleys of Antarctica. Antarctic Science, 21, 89-94.

Mellon, M.T., McKay, C.P. \& Heldmann, J.L. 2014. Polygonal ground in the McMurdo Dry Valleys of Antarctica and its relationship to ice-table depth and the recent Antarctic climate history. Antarctic Science, 26, 413-426.

Pollard, W., Doran, P. \& Wharton, R. 2002. The nature and significance of massive ground ice in Ross Sea Drift, Garwood Valley, McMurdo Sound. Royal Society of New Zealand Bulletin, 35, 397-404.

Pollard, W.H., Lacelle, D., Davila, A.F., Andersen, D., MacKay, C.P., Marinova, M. \& Heldmann, J. 2012. Ground ice conditions in University Valley, McMurdo Dry Valleys, Antarctica. Proceedings of the 10th International Conference on Permafrost, Salekhard, Russia.
Rignot, E., Hallet, B. \& Fountain, A. 2002. Rock glacier surface motion in Beacon Valley, Antarctica, from synthetic-aperture radar interferometry. Geophysical Research Letters, 29, 10.1029/2001GL013494.

Shean, D.E. \& Marchant, D.R. 2010. Seismic and GPR surveys of Mullins Glacier, McMurdo Dry Valleys, Antarctica: ice thickness, internal structure and implications for surface ridge formation. Journal of Glaciology, 56, 48-64.

Steig, E.J., Morse, D.L., Waddington, E.D., Stuiver, M., Grootes, P.M., MaYewski, P.A., Twickler, M.S. \& Whitlow, S.I. 2000. Wisconsinan and Holocene climate history from an ice core at Taylor Dome, western Ross Embayment, Antarctica. Geografiska Annaler, 82A, 213-235.

Sugden, D.E., Marchant, D.R., Potter, N., Souchez, R.A., Denton, G.H., Swisher, C.C. \& Tison, J.L. 1995. Preservation of Miocene glacier ice in East Antarctica. Nature, 376, 412-414.

Swanger, K.M., Marchant, D.R., Kowalewski, D.E. \& HeAd III, J.W. 2010. Viscous flow lobes in central Taylor Valley, Antarctica: origin as remnant buried glacial ice. Geomorphology, 120, 174-185.

Swanger, K.M., Marchant, D.R., Schaefer, J.M., Winckler, G. \& HeAD III, J.W. 2011. Elevated East Antarctic outlet glaciers during warmer-than-present climates in southern Victoria Land. Global and Planetary Change, 79, 61-72.

Yau, A.M., Bender, M.L., Marchant, D.R. \& Mackay, S.L. 2015. Geochemical analyses of air from an ancient debris-covered glacier, Antarctica. Quaternary Geochronology, 28, 29-39. 